\title{
Discovering Our Full Potential: Resuscitating the Female Principle
}

\author{
Tina Lindhard \\ International University of Professional Studies (IUPS), Maui, HI, USA \\ Email: t.lindhard@iups.edu
}

How to cite this paper: Lindhard, T. (2019) Discovering Our Full Potential: Resuscitating the Female Principle. Open Journal of Social Sciences, 7, 175-197. https://doi.org/10.4236/jss.2019.78013

Received: July 19, 2019

Accepted: August 17, 2019

Published: August 20, 2019

Copyright $\odot 2019$ by author(s) and Scientific Research Publishing Inc. This work is licensed under the Creative Commons Attribution International License (CC BY 4.0).

http://creativecommons.org/licenses/by/4.0/

\begin{abstract}
For a new evolutionary step forward, this study suggests humans need to learn to live from the heart and not only the mind. Here I associate the mind with the Masculine Principle and thinking which with learning, develops into intellect. This is contrasted with intuition which I associate with the Female Principle and the deeper heart-mind. They are different epistemological ways of knowing which reflect different levels of consciousness of the Self where each way of knowing has a different origin, the surface mind and the deeper heart-mind. Each gender can tap into both ways of knowing but most mothers have easier access to intuitive knowing, especially when obtaining information about the wellbeing of their children and loved ones. Connecting with the deeper Self using heart-based meditation methods, leads to insights about the different levels of consciousness and awakens one's intuitive abilities. Although intuition is attracting attention in different scientific fields, the connection between the deeper Self and intuition still needs to be recognized and explored by modern-day science. Different reasons why intuition linked to the female principle has been systemically depreciated for over two thousand years is also explored including questioning the origin on which the Western Intellectual Tradition is said to stand. To create a more caring, creative society, I propose that we need to resuscitate the female principle linked to intuition by reconnecting with our feeling heart-mind. Nevertheless, I advocate that we need both ways of knowing to unfold our full potential. This analysis has multiple implications which I address in the discussion.
\end{abstract}

\section{Keywords}

Intuition, Evolution, Self, Heart, Mind, Emotion, Feeling, Female Principle, Male Principle, Rational, Full Potential, Epistemology, Meditation

\section{Introduction}

In this paper, I address the topic of Intuitive Knowing or Direct Knowing, and I 
propose developing intuition as well as reason associated with our rational thinking mind is vital if we are to develop our full potential. I suggest intuition is one of the ways we receive information from our deeper Self or soul [1] [2] [3] [4] [5] which can facilitate knowledge about our loved ones and creative insights to our unsolved problems. Our deeper Self, soul, or the "unconscious mastermind" is related to a "mother-like awareness of intelligence" (Arka in [6], p. 42) that pervades every cell in the body. I also advance the idea that intuition is feeling based; an emotional faculty connected with the feeling heart-mind [1] [6]. The nature of the Self is discoverable through direct experience as one descends from the thinking mind to the feeling heart-mind using a heart-based meditation method such as Prayer of the Heart $(\mathrm{PH})$ or the Intuitive Meditation method (IM).

From the perspective presented here, intuition is an epistemological way of knowing through which we may receive guidance in our lives. I contrast intuition with the rational way of knowing associated with the Male Principle connected with the Thinking Mind. Influenced by the Theory of the Six Main levels of Consciousness [1], I consider intuition and thinking different epistemological ways of knowing which reflect different levels of consciousness of the Self where each way of knowing may have a different anatomical origin.

The intuitive way of knowing abounds in both the Old and New Testament where dreams, visions, precognition and direct non-verbal communication with or from a Higher Source are mentioned [5]. The direct or intuitive way of knowing is also recognized in the Indian tradition where a distinction is made between Sruti and Smriti. In the Vedas, Sruti or Shruti refers to texts and some commentaries on the original verses that arise from information that is "heard" [7] [8] rather than smriti or information that is remembered [9].

Before the development of our intellectual system, intuitive intelligence was considered normal. Before there were teachers or books, people must have looked up into the night sky and wondered: Who am I? How did all this come into existence? What are the laws of nature? Those who were sincere and persistent took their questions deep into their hearts and waited for Nature to give them an answer. In India, these people became known as philosophers, seers, rishis and yogis [1] [5] [6]. These mystical philosophers or inner scientists turned their attention inward to study, explore, and discover information about any topic including the nature of their inner Self. This was based on the premise that if they came to know their nature, they would know the nature of the Universe [5] [10]. In their aims, they are not so different from modern-day scientists as both want to acquire knowledge about life and the nature of the Universe. However, scientists in Western tradition go about their enquiry differently and study the nature of the outside world using their senses or extensions of them. In spite of this, scientists also use deep pondering at the beginning of their inquiries which gives rise to intuitive insights that they then test using the scientific method. However, they rarely acknowledge this initial phase [1]. 
Intuition is the "power of obtaining knowledge that cannot be acquired either by inference or observation, by reason or experience" was also recognized by Western Philosophers such as Kant, Spinoza, Bergson. Bergson, Dewey and Whitehead saw it "as a kind of intellectual sympathy through which it is possible to enter into objects and other persons and identify with them". Intuition sometimes referred to as insight, is "the understanding that takes place without overt trial-and-error testing. Insight occurs in human learning when people recognize relationships (or make novel associations between objects or actions) that can help them solve new patterns" [11].

Transpersonal Psychologists (e.g. [12]-[17]) investigate the nature of intuition and it is getting a new lease of life from the business sector where it is connected with decision-making at managerial level [18] [19].

In this article, I explore various aspects of intuition including its link to the Female Principle, the Self or soul, and its connection with heart-based meditation methods. Among other things, I also overview some of the historical aspects including myth, which probably led to the depreciation of intuitive knowing associated with the female principle, and the rise of the rational way of knowing in Greece. I look at the connection of the early Greek Philosophers with the Mystery Schools of Egypt and I question the basis on which Western Intellectual tradition is said to stand.

I propose that modern society needs to reconnect with the female principle and intuitive knowing to find solutions to the many problems facing humanity today. Nevertheless, I advocate that we need both ways of knowing to unfold our full potential. The analysis conducted here has many implications which I address in the discussion.

\section{Consciousness and Intuition}

\subsection{Mothers and Intuition}

Intuitive knowing seems to be an ability or faculty, which most mothers have, being "naturally available and readily accessible to help them understand the intense needs of their children and people they care about" ([1], p. 37).

In his Theory of the Six Main Levels of Consciousness, Arka [1] links intuition with the third level and he names it Feeling-Mind Consciousness. According to him, this level "generally prevails in the heart area and can thus be called the Heart of Heart-Consciousness. It includes an emotional faculty called intuition" ([1], p. 37). Arka associates this level with a connection to the soul, which he defines as the unconscious mastermind within every organic material in the body that pervades inside and outside of every cell, a mother like awareness of intelligence which prompts everything that happens biologically, psychologically, emotionally, or in any other way. It can be bigger than our bodies and smaller than a photon. One's truest identity, cosmically spiritual in nature (Arka in [6]).

Plotkin [20] considers the soul as the "mysterious, and wild core of our indi- 
vidual selves... (which ultimately) exists as an agent for spirit” ([20], p. 25).

\subsection{Thinking Mind Consciousness and Feeling-Mind Consciousness}

Arka [1] suggests both Thinking Mind Consciousness and Feeling-Mind Consciousness are properties of Consciousness or Conscious Spirit [5] [6].

Consciousness manifests itself through physical matter. Similar to bacteria that are able to survive with a complete lack of oxygen and in high temperatures, consciousness lacks boundaries, can take any form or shape and can emerge under challenging life conditions. In spirituality, consciousness is mainly a non-physical yet powerful entity that is the pivotal point of all life and activates the senses in every living being. It is highly responsive and expressive and activates many levels, especially in humans. ([1], p. 37).

This definition forms the basis for Arka's [1] theory of the Six Main Levels of Consciousness. It is derived from his personal experiences and that of his pupils when using a heart-based meditation method known as the Intuitive Meditation method. This method is said to open the practitioner's intuitive abilities which give rise to Intuitive Intelligence [1].

Lindhard [3] [4] [6] conducted an exploratory study to discover if people would show a trend toward a more feeling-based conscious after receiving training in the heart-based Intuitive Meditation method (IM). This method involves training people to go below their thinking minds so that they may connect with their Self via the heart. It is non-denominational and based on touch, breath and a vibratory sound. In her study, she developed a scale (Feeling Consciousness Scale-FCS) to measure the changes in the quality of consciousness of people when they start meditating on the Self or soul via the heart. Using a repeated measures design, a significant difference at the 0.001 level was found between participants scores before learning the method and measured again after receiving five IM training sessions spread over six weeks (a total of 13.5 hours). Statements from the open questions supported these results. The open answers indicated that participants felt more peaceful, centred, connected to their inner essence or soul and intuitively guided. This study gives support for the existence of the third level of Consciousness suggested by Arka's theory, but the study needs repeating using bigger sample size and more male participants. The other levels mentioned in this theory, also need to be investigated. The levels involve deepening states of certain qualities of consciousness that are experienced by practitioners as they advance in their journey into the true nature of their consciousness. Although different levels can be identified, the contents of each level are different for each practitioner.

\subsection{The Mind of the Heart and Intuition}

According to Louchakova [21] the phenomenological analysis of the Prayer of the Heart $(\mathrm{PH})$ "uncovers the inner structure of consciousness within this 'mind 
of the Heart' as opposed to 'mind of the head" She refers to the "mind of the heart" as being gnostic or knowing. "Data from the focus groups show that intentional consciousness associated with the head usually consists of self-reflective, analytic/synthetic, logic-based constructs as opposed to the lived experience in the chest" ([21], p. 295). As such, findings from Prayer of the Heart are consistent with the initial levels outlined by Arka [1] in his theory.

Armour [22] [23] [24] found that the heart has an intrinsic nervous system of its own which has been characterized as a brain on the heart or heart-brain. $\mathrm{He}$ suggests that intuition begins to function at the level of the heart. The heart has also been found to send more signals to the brain than vice versa [25]. McCraty, Atkinson, and Bradley [26] [27] have found that the heart is involved in the processing and decoding of intuitive information. Using a very clever design, McCraty, Atkinson and Bradley [26] [27] have shown that the heart receives and processes information about an event before the event happens. The heart also appears to receive intuitive information a few seconds before the brain.

Friedman [15] draws a parallel between intuition and emotional knowing which is linked to a more primitive preverbal way of knowing which is "not cognitively mediated" ([15] p. 184). According to HeartMath, there are four communication pathways between the heart and the brain: neurological, chemical, biophysical, and energetic [6] [28].

Oschman [29] talks of authentic actions and thoughtful actions. In his theory, the first arises from information received directly from the living matrix subconscious, whereas thoughtful action arises from the neurological pathway. Whereas Oschman seems to be talking about how information comes into the system, Ramirez [30] and Arka talk about how we can access information that is beyond our sensory awareness. However, all of them seem to concur that the human being can access information which does not arrive in the normal way through the senses and the neurological pathway [31]. "We do not know the limits of sensory awareness. Certainly you 'know' a lot more than you think you know" [1].

\section{Meditation}

\subsection{Self-Pondering and Meditation}

Anybody who has tried to turn their attention inward will be aware this is no easy task, for often the first thing one notices is how prevalent one's thoughts are and maybe one might be continually distracted by pains or discomforts in the body. To help in this task yogis developed methods, which lead to meditation. The methods are in themselves not meditation, but they certainly help give rise to different inner experiences and states which, when coupled with contemplation, not only lead to an awareness of the deeper nature of the Self but also experiencing it [6].

Heart-based meditation is a core of practices associated with ego transcendence and contemplation of the Self and involves the "experimental phenome- 
nological introspection into the living topological construct of the Self" ([32], p. 82). For Arka [1] the term meditation entails "serious self-pondering [which involves] the process of making profound inquiry into the depth of the soul about... [our] existence or how the Universe was created or the laws that governed living and non-living matter" ([1] p. 29).

\subsection{Prayer of the Heart}

In contrast to the meditation method known as Mindfulness, there is little scientific research on heart-based meditation methods (Louchakova \& Warner as cited in [32], p. 84), probably because the differences between the methods in regarding their objectives are, as yet, little understood by many scientists. Heart-based or heart-centered methods are feeling based and include focusing one's attention on the psycho-spiritual center of embodied consciousness in the center of the chest, or heart center. Although the HeartMath Institute has begun researching different aspects of the heart, scientists have yet to discover the nature, role, and importance of this center to us as embodied beings.

The oldest well-known heart-based method is called Prayer of the Heart (PH) was practised in one form or another for thousands of years by many cultures. Notably, the ancient Egyptians, Jews, Persians, early Christians, Sufis as well as different cultures in the Mediterranean area were versed in it. $\mathrm{PH}$ is also close to the traditions involving Self-enquiry (Atma-vichara) and Kashmiri Shaivism. "It is rooted in an understanding of the Godliness of man and the humanness of God" ([2], p. 35).

\section{Ancient Greece}

\subsection{Know Thyself and Delphi}

Given the extensive use of Prayer of the Heart in the Mediterranean area, it seems probable that it was also practised by the ancient Greeks. In Delphi, the maxim Know Thyself, which was inscribed on the forecourt temple of Apollo, is a point in favour of this argument. It also seems likely the Pythias, the women who pronounced the oracle at Delphi and the Sibyls prior to them might have been students of this ancient esoteric art. Lindhard [33] points to the multiple meanings of the term virgin (Parthenos), which also means pupil. However, she also points out that one who has reversed their personal history through spiritual endeavour can be considered a virgin or somebody who is pure and from the "first pressing". In this sense, the person would be able to access information directly or freshly, as it is "not altered by human activity or ego" ([33] p. 483). In this sense, the term virgin can be applied to females and males [5].

The connection of Delhi with the Egyptian Mysteries becomes obvious as when the first temple was burnt down in 548 BC, it was the "Grand Master Amasis King of Egypt, who unhesitatingly donated three times as much as was needed for the purpose" of rebuilding it ([34], Notes, Chap. III, no 3).

The Pythias could also have arrived at the trance state, not though mystical 
union, but through the inhalation of gasses (probably ethylene) that escaped from the fissures on which the temple was situated [35]. There seems to be some support of this, as, according to Plutarch, who served as a priest at Delphi during the late first century and early second century CE, the Pythias lives were shortened through their service to Apollo. However, he also qualifies that "the power of the spirit does not affect all persons nor the same persons always in the same way... The power comes from the gods and demigods..." ([36], n.d. verse 51, para 2).

The claim that the Pythias might have spoken in a drugged frenzy which then needed interpreting by the male priests, does not seem to be supported by most ancient sources which reveal that the Pythias spoke intelligibly and gave prophecies in their own voices [37] [38]. Putting together the evidence seems to suggest that some of the Pythias might have been mystics in their own right and spoke using their own voice, whereas others were not so proficient, and their trance might have been drug-induced. In talking about demi-gods, Plutarch, says "with some of these souls it comes to pass that they do not maintain control over themselves, but yield to temptation and are again clothed" ([36], n.d. verse 10, para 2). This too can also be seen as applying not only to demi-gods but people who are connected to their souls and who then lose this connection because of unresolved emotional habits or because of the temptations of material life. Our whole life can be seen as an adventure in discovering and reconnecting with our Self or soul again [39].

\subsection{Conditions of Women during the Classical Period}

During the classical period, an arbitrary division of a few thousand years, which incorporates the "history and culture dominated by Greek and Roman influences" ([40], para 7), a woman in Greece was supposed to be silent and thus in politics and power lacked any right to be heard ([41], p. 37). However, paradoxically, in Greece and Rome women were pronouncers of oracles and existed side by side with the philosophic and mathematical way knowing as expounded by Pythagoras ([42], Prologue), Ironically, because of Pythia's fame as the pronouncer of oracles, the greatest authority of ancient Greece was a woman and the most famous site was Delphi ([42], Chap 1), But we must also remember that women did not pronounce the oracle in their own right, but as a vessel through which the male god Apollo spoke [33].

In talking about the role of the priests in Delphi, Plutarch [36] claimed they guarded the chastity of the priestess, and "keep her life free from all association and contact with strangers, and take the omens before the oracle, thinking that it is clear to the god when she has the temperament and disposition suitable to submit to the inspiration without harm to herself" ([36], verse 51, para. 3). I leave each reader to make of this statement, what he or she will.

\subsection{The Voice of the Gods, the Nature of Prophesy and the New Vision}

Plutarch worked at Delphi when the site was already losing popularity and on 
being asked why, he responded many of the oracles in Greece had ceased to function because the population in Greece had declined so there was less need for oracles then than in previous times [36]. In commenting on the nature of prophecy, Plutarch recognized the hand of god in this ability but he felt that it was "foolish and childish in the extreme to imagine that the god himself after the manner of ventriloquists... enters into the bodies of his prophets and prompts their utterances, employing their mouths" ([36], n.d. verse 9, para 2). In talking about prophecy he felt that nothing given is imperishable and the "wise men are ever telling us we must look for (the power and presence of the gods) in Nature and in Matter, where it is manifested, the originating influence being reserved for the Deity, as is right" ([36], n.d. verse 9, para 2).

This comment can be seen as reflecting a shift away from seeking the will of the gods through prophetic predictions pronounced by the oracles, to embracing the study of reality where the hand of the gods can be seen in the manifestation of Nature and Matter.

\subsection{Pre-Classical Period}

In pre-classical times, and also during the same period later identified as classical in Greece and Rome, the intuitive way of knowing abounded in other Mediterranean countries where the Biblical stories unfolded. As stated earlier, in the $\mathrm{Bi}$ ble both men and women seemed to have access to this way of knowing which can be considered as a guiding principle.

In pre-classical Greece, Delphi was known as Pytho, the same name as the great serpent, which was said to guard it. It was a place of goddess worship and the python was the symbol of rebirth, transformation and regeneration and was considered the son of Gaia, the Earth goddess. Pytho was also a place of prophecy when a "mystical sibyl" presided there. "Sibyl" comes from the Greek word Sibylla ([43]. P.30) and means prophetess or "one who sees" and they were found all over Greece. When the oral goddess tradition was replaced by invading patriarchal societies, the myths were wiped out or retold and transformed to suit the new tradition.

\subsection{Replacement Myths}

In Delphi the masculine Olympian God Apollo replaced the earth Goddess and the semi-divine priestesses were also replaced by human oracles who became known as the Pythias, which comes from the Greek word pythein meaning "to rot". This referred to "the stench from the body of the Python, which arose from the fissure Apollo had thrown the slain serpent into" ([43], p. 33). Apollo's killing of the serpent was re-enacted at the beginning of the Delphi games, which were initially celebrated every eight years from about $800 \mathrm{BC}$ and after $580 \mathrm{BC}$, every four years. As Delphi was finally closed in $393 \mathrm{AD}$, the consistent repetition of the myth spans more than a 1000 years.

Although understandable from the point of view of the new patriarchal re- 
gime, this can be seen as a very powerful way of depreciating the former feminine religion and its symbols.

\section{Myths and Symbols}

\subsection{The Snake as Symbol}

To understand the full extent of the depreciation of women, one has to understand the snake or python as a symbol. As already stated, the snake is the symbol of rebirth, transformation and regeneration. But it is much more than that. According to Campbell

The power of life causes the snake to shed its skin, just as the moon sheds its shadow. The serpent sheds its skin to be born again, as the moon its shadow to be born again. They are equivalent symbols. Sometimes the serpent is represented as a circle eating its own tail. That's an image of life. Life sheds one generation after another, to be born again. The serpent represents immortal energy and consciousness engaged in the field of time, constantly throwing off death and being born again. There is something tremendously terrifying about life when you look at it that way. And so the serpent carries in itself the sense of both the fascination and the terror of life. ([44], answer 2).

The snake is about life energy and consciousness incorporated in a temporal body and as women are givers of life, they are associated with the snake. As such, women are a reminder of the fall of "man" from timeless non-dual consciousness [44]. By depreciating woman, one, by association, is also depreciating life itself.

\subsection{Male-God-Oriented Group Myths}

The fall from timeless non-dual consciousness seems to be the reason some cultures associate women with sin, for she gives birth to life in a world, which is dual. We find this depicted in the story of the Garden of Eden [44].

A historical example and manifestation of this belief occurred in the Hebrew subjugation of the Canaanites, whose principle divinity was the Goddess and her symbol the snake, which represents the mystery of life [44].

Likewise, the followers of Apollo, another male-god-oriented group, rejected the Python and all that is associated with it. In fact, in killing the python, the myth of Apollo can be seen as going further than the Hebrews in their myth. To add force to the myth, it was enacted at the beginning of at the Delphi Games, which comprised of not only sport but also music. These games took place at regular intervals for over 1000 years.

Women were subjugated in Greece where, as already pointed out, in public discourse they were supposed to be silent and in politics and power lacked any right to be heard ([41], p. 27). Ironically the Pythia was the most powerful person in Greece, especially as she not only pronounced on private matters but also affairs to do with politics and the state. 


\section{Possible Repercussions on a Psychic Level}

From a scientific view, proving repercussions is very difficult. However, one can suggest some of them. On an emotional level, what we do to others affects the doer first [10] so by association through the python, men were "slaying" the female aspect of themselves. In the terminology of Jung [45], it would become part of the shadow, the dark or unknown side of the personality, which is prone to psychological projection. Interestingly, this perceived personal inferiority is recognized as a perceived moral deficiency in someone else [46].

Whereas Jung [47] talked about the anima and animus, I prefer to talk about the male and female principle and here I mainly restrict my usage of these terms to the alternative ways of knowing associated with each principle.

As we have seen, intuitive knowing gives rise to guidance through intuition. The dependence on the oracle of many men in ancient Greece can be seen as an example of lack of inner guidance. Not only did men seek guidance in how to act regarding private matters but also affairs to do with politics and state. Women also consulted the oracle but had to send men in their lieu.

I cannot and am not trying to prove a causal connection between the myth of the slaying of the python by Apollo and the lack of guidance through intuition in men; I feel there are always multiple reasons for any behaviour. My intention here is to point out some of the patterns that can be observed. Bringing unconscious patterns to light or conscious awareness is an important task for it is said "who do not know their history, is condemned to repeat it" ([48], p. 284).

The lack of conscious connection by men with their inner guiding voice may also be seen as having its positive side for it seems to have provided the impetus for men to develop a different way of knowing, later termed the rational way of knowing. And if it did not directly provide the impetus, at least it might have provided some of the ground for its development. The early Greek male philosophers who were later identified as developing the rational way of knowing, lived side by side with women who formed a "sisterhood of mystics" ([42], Prologue) who pronounced the oracles [33]. However, in a later section in this paper, I question if many of the insights of the early Greek Philosophers truly arose from the thinking mind and suggest they probably arose through intuition. I also question where or from whom the early Greeks Philosophers acquired their knowledge.

\section{Definitions}

For me, the heart of the dilemma, which takes us up to the present day, is the lack of clarity regarding the source of intuition and rationality. But first, let us look at what these terms mean.

\subsection{Intuition}

Intuition: the power or faculty of attaining to direct knowledge or cognition without evident rational thought and inference [49]. 
To highlight this usage, I share a mythical account of the story regarding the writing of the Bhagavad Gita, the most famous epic poem of India, which involves a discourse between Krisna (god) and his pupil Arjun. The scribe who took down the tale was said to be the elephant god Ganesha. He was told to take down the story without stopping. So, when his pen failed halfway through, he quickly broke off the point of one of his tusks and used it to continue writing. Today all images of Ganesha have a part of one of his tusks missing as a reminder that when direct intuition is flowing from god (also known as soul or Self), one must not stop or let the rational mind interfere with what is being relayed.

A modern-day definition of intuition states "the mental faculty for making immediate direct connections between two or more ideas analogous to vision... the related ideas may be abstract objects or properties or feelings" ([51], p. 9). This knowing takes place without the conscious use of reasoning.

\subsection{Rationality and Reason}

Reason: 1) "the power of comprehending, inferring, or thinking especially in orderly rational ways". 2) "the sum of the intellectual powers".

Archaic definition: treatment that affords satisfaction [50].

For Spencer, rationality (reasoning) is known as the mental faculty of reason... and it is distinguished from memory, imagination or (religious) belief; its admirers believe its results are intellectually trustworthy ([51], Section 1, p.1). He also points out that dictionaries point to its "role in Truth-seeking and Problem solving" ([51], p. 1). Reasoning involves a process, which is like speech in that one statement leads to another. In this, it is also like mathematics and logic, both intellectual methods of establishing the "correctness of results of valid reasoning (a belief is 'true' or the problem solution is appropriate)" [51].

Inherent in the act of rationalizing is the "psychological self-deception of making up plausible excuses for one's acts and beliefs (where the actual word rational) closes the circle by relating it to reason, deliberately linking it to thinking, sanity, sensible and non-foolish" ([51], p. 1).

The rise in reason and the rational way of knowing in science has been accompanied by a decline in intuition or at least the acceptance of its existence. Many scientists classify research into intuition and psych phenomenon as pseudoscience in spite of there being quite strong statistical evidence which would "be widely accepted if... (this data) pertained to something more mundane. Most scientists reject the possible reality of these abilities without ever looking at the data" [52].

\subsection{The Basis of Intuition and Rationality}

Although the above-mentioned definitions specify the differences between the rational and intuitive way knowing, the modern-day tendency of writing off intuition, seeing it as a property of the mind or as intuition and rationality being 
"mental faculties", does not tell us very much about their source or origin. And it is here that I agree with La Tour and La Tour [53] that it is only people who have explored the nature of their own consciousness who can throw light on this interesting and vital question. In the theory of the Six Main Levels of Consciousness talked about at the beginning of the paper, both ways of knowing are expressions of the deeper Self, soul or conscious spirit, however, they represent different levels of consciousness. The rational way of thinking, "sharpened by the cultivation of learning... evolves into a faculty called intellect" ([1], p. 37). is often associated with the surface of the brain. Intuitive knowing, on the other hand, is an emotional faculty, which is associated with the mind of the heart. I associate the former with the masculine principle and the latter, the female principle.

Arka's theory gives a new way forward in that individuals can investigate it more thoroughly through science and also personally, through inner exploration and discovery. The interesting thing is it recognizes thinking mind consciousness associated with the intellect and also incorporates intuition and the female principle, which, I argue here, was depreciated in Apollo's slaying of the python. But before I go further into this, let us look at the rise of Greek Philosophy.

\section{Greek Philosophy}

\subsection{The Rise of Greece Philosophy and Rational Thought}

Before the rise of philosophy in Greece, "myths explained natural phenomena (the sun was carried around the heavens by Apollo's chariot; Zeus hurled thunder and lightning from the top of Mount Olympus). Early philosophers attempted to provide uniform, rational explanations for the 'world order' or kosmos and nature" ([54], 2PL).

On a timeline, the different schools of Greek Philosophy all came into existence after Apollo was said to have slain the Python after his arrival at Delphi. Scott [55] gives the date of Delphi's use as a sanctuary of Apollo as the late eighth century BCE. Greek Philosophy as an independent cultural genre began around $600 \mathrm{BCE}$, and its influence persists today [56].

Greek Philosophers rejected mythology and the poetry of Homer and Hesiod and they sought to replace this way of conceptualizing reality by explaining things in terms of impersonal Nature. The break was not sharp but it involved a rejection of "the pseudo-science of divination, where one tries to know the minds of the gods" to explain "things using reason, logic, evidence, argument, and rational criticism (tests)" The fundamental questions also changed to what and how, rather than who or why ([54], $\pi 07002 \mathrm{~F})$.

Daniels [57] identifies two different philosophical currents as practiced by the Greeks:

- naturalistic

- mystical

"Some like Socrates, Aristotle, Marcus Aurelius merged the two currents in an 
attempt to do justice to the informable complexity of life," "But even in these men the dominant strain, characteristic of Greek thought, was the love and pursuit of reason." ([Durant in [57]).

\subsection{Roots of the Western Intellectual Tradition}

The roots of the Western intellectual tradition are said to stem from the Greeks, but it seems this is not entirely accurate. Thales (640 B.C.) received his education in Egypt, and his associates Anaximander and Anaximenes, who were also natives of Ionia in Asia Minor, adhered to the Egyptian Mystery Schools, as did Xenophanes (576 B.C.), Parmenides, Zeno and Melissus and Pythagoras [58]. It seems Ionia was a stronghold of the Egyptian Mystery Schools, whereas Athens was against these teachings, hence the sentencing to death of Socrates in 399 BC and the fleeing of Plato and Aristotle from Athens as "philosophy was something foreign and unknown to them" (i.e. the people of Athens) ([34], part 1, para 3).

History, according to James [34], makes it clear that the teachings of the Egyptian mysteries are the true authorship of philosophy and neither the Ionians nor the Italians, where these teaching had spread prior to them being accepted in Athens, ever tried to claim authorship of them. In support of his claim, James points out that there is "a complete absence of information about essential information concerning the early life and training of the so-called Greek philosophers, from Thales to Aristotle" ([34], Section 2, para 1). In other words, the history of Greek philosophy is said to arise from men about whom history knows next to nothing "yet expects the world to accept them as the true authors of the doctrines which are alleged to be theirs" ([34], section 2, para 3). The lack of the publication by the early philosophers is understandable as the publication of the information was contrary to the rules of the Egyptian Mystery. Hence the Book on nature entitled Peri physeossaid to date back to the sixth century BC, was probably not produced by genuine Initiates ([34], Section 2, para 5]).

Egypt was the centre of the body of ancient wisdom, and from there religious, philosophical and scientific knowledge spread to other lands through student Initiates [34]. Vial [59], (1909) suggests its origins can be traced to the "far Eastto the earliest civilization, from which time and place they have spoken in nature's language to all peoples of the earth" ([59], p. 9]). Empires and civilization come and go, but this information carved in stone in rock temples and elsewhere, continue to "convey the Great Secret" ([59], p. 10) to future generations. Hence the Egyptians were probably not the origin of the esoteric tradition they taught. Veil credits the "Sons of Venus" as the source although they are sometimes known by different names ([59], p. 14). The Institution of the Mysteries was found in Egypt, Persia, Greece, Samothrace and Chaldea, India, the Druidical Mysteries, and many others ([59], p. 10) and forms the basis for all religions ([59], p. 14).

According to James [34], it was after the conquest of Egypt by Alexandra the Great that looting of the Royal Library at Alexandria occurred. Aristotle's pupils then usurped this knowledge to form the basis of what became known as Greek 
Philosophy ([34], Section 3, para 2). The Memphite theology, which is engraved in stone and said to date from $700 \mathrm{BC}$, already contains information attributed to the later Greek Philosophers. The theology itself has been assigned to a very early period of Egyptian history (between 4000 and 3000 BC) ([34], Chap VIII).

Whether James's accusations are true or not does not directly concern us here. However, what does concern us is that the Western intellectual tradition chose reason as its base which they attributed to the Greek Philosophy. This has cut this tradition off from its base in the Mystery Schools and its love of truth. The main objective of the Egyptian Mystery System was "the deification of man: They taught that the soul of man, if liberated from its bodily fetters, could enable him to become godlike and see the Gods in this life and attain the beatific vision and hold communion with the Immortals" ([59], p. 25). And this brings us back to the heart-based meditation methods discussed at the beginning where intuition is the key to realizing knowledge of the Self.

\section{Deeper Reality}

\subsection{Pure Consciousness}

Arka [1] describes the journey to Self-discovery as "a journey from the Rational Mind to the Emotional Heart to Pure Consciousness" ([1], p. 38; 38). When using the heart-based IM method, the practitioner goes through six main levels to achieve Pure Consciousness. The journey includes rewinding our surface consciousness to reverse everything that has happened to us [1]. This has some parallels with the four specific stages proposed by Grof and Grof [60] in the healing process: 1) the sensation phase 2) the biographical stage 3 ) the perinatal stage, and 4) the transpersonal stage.

Pure Consciousness or Pure-Self-Consciousness is the sixth layer Arka [1] identifies. This is the "very essence of your whole presence and of everything that you feel, think and do. It is addressed as Soul or Self" ([1], pp. 37-38).

In Classical Indian writings such as the Upanishads, "consciousness is thought to be the essence of Atman a primal, immanent self that is ultimately identified with Brahman, a pure, transcendental, subject-object-less consciousness that underlies and provides the ground of being of both Man and Nature" (Sen in [61], p. 1). The quality of its consciousness is referred to as Sat Chit Ananda, pure Being, pure Knowing, and pure Bliss [62].

In IM, the journey to pure consciousness involves a return to our innocence where we learn to listen to Nature's guiding wisdom through our Feeling Hearts. The source of this guiding inner voice is referred to differently by different people and traditions, some seeing it as voice of God. It is, however, not the name that is important, but the capacity of people to connect with their feeling-heart mind from which intuitive guidance is whispered silently. Feeling is "like 'mother sense', the mother of mother sense... without its involvement... [we] cannot grasp anything" (Arka in [6], p. 158).

Many meditators feel keeping the mind blank is what meditation is all about. 
It is not; at least heart-based meditation methods are not about this. In meditation one can go above the mind (thinking mind) or below it; going below it is easier (Arka in [6]). Intuitive Meditation is about connecting with the deeper Self, a state of Silence from which all arises. Silence is the true nature of Consciousness and it is on entering into this state, that deeper experiences and/or knowledge about one's subject of interest may arise. It can happen naturally like when one is relaxed and in the bath. It can also be entered at will through training in certain meditation methods where one invites ones surface consciousness to descend to the heart level [6].

\subsection{Different Names for the Underlying Deeper Reality}

On one hand, we have names that refer to our deeper nature and on the other hand, we have names for the underlying deeper identity of the universe. As we have seen, our underlying identity is often addressed as Self soul, or atman. According to Plotkin [20], (2003), the soul is an "agent of Spirit". "By spirit I mean the single, great, and eternal mystery that permeates and animates everything in the universe and yet transcends all” ([20], p. 25). Some call It Higher Nature or Mother Nature, whereas others call it That. In India the highest Universal Principle, the ultimate reality in the universe is known as Brahman [63]. It is also referred to as the primal, immanent Self, which provides the ground of being of man and Nature.

Goddess traditions and the Taoist tradition identify it as the "Womb" from which all arises [64] [65]. Others refer to it by the different elements through which It manifests-water, fire, air or space-also Apeiron-the "infinite".

It is also identified by the quality of the experiencing Consciousness-Pure Consciousness or Sat ChitAnanda-pure Being, pure Knowing and pure Bliss or as having properties such as Omniscience, Omnipresent and Omnipotent.

In Quantum Physics Bohm [66] calls the underlying reality the implicate order, whereas, in the newer versions of quantum theory, they talk of the Unified Field of Consciousness [67]. The Bhagavad Gita talks about the field and the knower of the field. In the discourse between Krishna and Arjuna, Krisna says "the body is called a field...; the one who knows it is called the Knower of the field. This is the knowledge of those who know. I am the Knower of the field in everyone, Arjuna. Knowledge of the field and its Knower is true knowledge" ([68], Chap 13).

Maybe the term God, Allah and YEHOVAH (YHWH) (the word that should not be spoken) is related to this topic.

\section{Discussion}

\subsection{Summing up}

This paper has two main thrusts. One has been to show that the history of the Western intellectual tradition ignores the connection of early Greek Philosophers with the Egyptian Mystery schools. This has helped to promote a tradition 
which is based on reason and the development of the thinking mind which with training, develops into intellect. I have argued here that this has cut people off from their intuition and appreciating or exploring of the meaning of the maxim Know Thy Self engraved in stone in the forecourt of the temple to Apollo in Delphi; a saying that similar to that found in the Luxor Temple in Egypt-"Man, know thyself, and you are going to know the gods" [69].

The second thrust involves exploring the nature of the Self. To facilitate this, I have made a distinction between thinking mind consciousness and feeling-mind consciousness; the first I associate with the male principle and the second with the female principle. One is based on thinking and the other is linked to intuition. The analysis presented adds to the research that supports people can access information and make decisions not based on analytic thought and is also in agreement with most people that "there is such a phenomenon as intuition, involving emotionally charged, rapid, unconscious processes" ([70], abstract).

As stated, many scientists do not credit that many of their ideas arise through intuition and when they do, they link intuition with the mind, which they usually associate with the brain. Although the relationship between mind and the brain has long been debated, Driver, Haggard and Shallice claim "advances in neuroscience have now led to wide acceptance in science and medicine that all aspects of our mental life-our perceptions, thoughts, memories, actions, plans, language, understanding of others and so on-in fact depend upon brain function" ([71], para. 1). This has led to a massive amount of neuroscientific research including the search for the neuronal correlates of consciousness (NCC) "where the brain as a whole can be seen as an NCC". ([72], heading 1, para 1). Although researchers suggest intellectual cognitive thinking is mainly associated with the prefrontal cortex [73] and emotions with the limbic brain stem [74], they do not have a model which helps us clearly distinguish cognitive mental processes involving analytical thinking from intuitive emotional functioning and the role of the heart in this process. They also do not have a theory which honours the full nature of the "being" who performs these activities.

It is here The Theory of the Six Main Levels of Consciousness provides a bold step forward in our knowledge of the Self by suggesting we have different levels of consciousness. In this theory, cognitive functioning involving thinking is associated with the surface of the brain and can be addressed as "Mind Consciousness" ([1], p. 37). Intuition is seen as an emotional faculty which is feeling-based and associated the heart and Arka identifies it as "Feeling-Mind Consciousness. According to this theory, among other levels, Mind Consciousness and Feeling-Mind Consciousness are different levels of consciousness of the Self which is expressing itself through the physical body. To access the third deeper feeling layer, one has to go below the thinking mind which Arka names as subliminal Mind Consciousness. Arka addresses the part of the Self that undertakes the inner journey as 'I awareness'," "I ego conscious awareness," or "I ego awareness" [75]. The "I awareness" is the pivot of the memories which form into 
a personality. "With the development of 'I ego awareness' a time arises when we want to touch the origin of consciousness expressing itself through the human body" ([Arka in [6] p.147). In the journey to Self-realization he talks about the need of the person to reverse all that has happened to him or her (2013). Other meditation approaches that meditate on the Self, talk of ego transcendence [76] [77] [78].

Arkas' model is not purely theoretical but arises out of his exploration into his own consciousness and the consciousness of his pupils. It involves a step by step procedure to know one's Self and the nature of one's consciousness which unfolds when one uses a heart-based method of mediation such as the IM method and probably PM, a method also used by the Egyptians [2].

\subsection{Implications}

The analysis performed in this article, has spiritual, theoretical and practical implications which are relevant to us personally, socially and scientifically. I outline some of the main ones in point form below:

1) There is a deeper aspect to every person beyond his or her "I ego-personality or identity" which together with this feature, makes up the totality of the person even though he or she may not be consciously aware of his or her deeper Self or the functions it performs. Here it is referred to as the Self, soul, or "unconscious mastermind".

2) Intuition is a faculty through which the deeper Self or soul can supply guidance regarding issues of importance to the "I ego personality".

3) To discover our true nature or Self, each person needs to undertake a personal journey to discover the nature of their consciousness. This is consistent with the maxim Know Thy Self written in stone in Delphi.

4) Scientists need to explore the nature of their own consciousness if they want to fully unravel the riddle of consciousness. Exploring it through the outside-in approach and speculating about it using the thinking mind [79] will never reveal the different qualities of consciousness as people proceed through the different levels.

5) On a practical level, the Theory of the Six Main Levels of Consciousness provides a new step forward in the study of Consciousness for it includes definable levels which are testable and reproducible using the scientific method. In this theory the levels are common but the connects of each level are unique [1].

6) This theory is scientifically testable through the use of scales like the one Lindhard [6] used in her investigation. Additional scientific measurements using technology such as the MCG, ECG, EMG, EEG, and the SQUID could be included which would give additional information about the levels from the outside-in perspective.

7) Combing some of these techniques with self-reports and GVD imaging (Gas Discharge Visualization Camera), or the PIP (Polycontrast Interference Photography) could also be undertaken to understand more about changes in 
the relationship between electric fields, the aura, the meridian, the chakra system and brain waves of seasoned meditators when they are absorbed in meditating on the deeper Self via the heart.

8) There are differences between meditation methods regarding their objectives. Using heart-based methods such as IM and $\mathrm{PH}$, if pursued, enables the practitioner to connect with their deeper Self and discover its nature.

9) The role of the heart and its link to intuition is under-researched. What exactly is meant by "heart" needs to be established but is beyond the scope of this paper.

10) The Western intellectual tradition has expanded its emphasis on reason and the formation of the intellect through the Western Educational system, a system which is being extended throughout the globe. This has serious implications for it has undermined educational systems of other cultures and alternative ways of knowing.

11) The female principle needs to be acknowledged and revered to bring balance and harmony to oneself and the world outside otherwise the "social and psychic structures become over mechanized, over-politicized, over militarized". At the same time "the need for relatedness, feeling, caring or attending to nature goes unheeded" ([80], p. 16)

12) To become fully functioning human beings, we need both the female and male principle.

\section{Conclusion}

For a new evolutionary step forward, this study suggests humans need to learn to live from the heart and not only the thinking mind. This is based on the analysis that we have two principle ways of knowing which are different and can be associated with the male and female principle, one based on thinking and the other based on intuition; one associated with the surface of the brain and the other with the heart, a deeper layer of our being which is connected with the deeper Self or soul. Arka [10] identifies three planes, living from the mind, living from the heart, and living in the core being ([10], p. 61). This article directs our attention to understanding more about intuition and living from the heart. This means "living with depth, with feelings, with emotions, and with creativity where the heart uses the mind to express its guidance" ([10], p. 61). However, to discover out full potential, we need to develop both, the heart first and then the mind [10]. Summing up Einstein's thoughts, Samples [81] says: "the intuitive mind is a sacred gift and the rational mind is a faithful servant. We have created a society that honours the servant and has forgotten the gift" ([81], p. 26).

\section{Conflicts of Interest}

The author declares no conflicts of interest regarding the publication of this paper. 


\section{References}

[1] Arka, S. (2013) Arka Dhyana Intuitive Meditation. An Enlightening Journey into Your Inner Realms Initiated by Your Breath, Sound and Touch. Coppersun Books, Middlesex.

[2] Louchakova, O. (2004) Essence of the Prayer of the Heart. In: Lozowich, L., Ed., Gasping for Air in a Vacuum, Holm Press, Prescott, 35-50.

[3] Lindhard, T. (2017) Experiencing Peace through Heart-Based Meditation on the Self. The Open Psychology Journal, 10, 27-40. https://doi.org/10.2174/1874350101710010027

[4] Lindhard, T. (2018) The Theory of Six Main Levels of Consciousness: A Study of the Third Level. Journal of Consciousness Exploration \& Research, 9, 100-121.

[5] Lindhard, T. (2018) Education, Myths and the Female Principle. Revista Asturiano, No. 212, 2-9.

[6] Lindhard, T. (2016) Unlocking the Secrets of the Heart through Meditating on the Self. PhD Diss., Dept. of Consciousness Studies, University of Professional Studies, Accra.

[7] Lochtefeld, J. (2002) "Shruti", the Illustrated Encyclopedia of Hinduism, Vol. 2: N-Z. Rosen Publishing, New York.

[8] Arka, S. (2018) Wellbeing: Through the Lens of Indian Traditional Conceptualisations. International Journal of Social Work and Human Services Practices, 6, 101-105.

[9] Editors of Encyclopaedia Britannica (n.d.) Smriti in Encyclopaedia Britannica.

[10] Arka, S. (2003) Becoming Inspired. Coppersun Books, London.

[11] Editors of Encyclopaedia Britannica (n.d.) Intuition in Encyclopaedia Britannica.

[12] Princeton Engineering Anomalies Research Library (1997) Intuition the Inside Story: Interdisciplinary Perspectives. Routledge, New York.

[13] Vaughn, F. (1998) Mental, Emotional and Body Based Intuition. In: Palmer, H., Ed., Inner Knowing. Consciousness, Creativity, Insight, and Intuition, Jeremy $\mathrm{P}$. Tarcher/Putman, New York.

[14] Anderson, R. (2000) Intuitive Inquiry: Interpreting Objective and Subjective Data. Revision, 22, 31.

[15] Friedman, H. (2002) Transpersonal Psychology as a Scientific Field. International Journal of Transpersonal Studies, 21, 175-187. https://doi.org/10.24972/ijts.2002.21.1.175

[16] Ferrer, J.N. (2008) Spiritual Knowing in Participatory Enaction: An Answer to the Question of Religious Pluralism. In: Ferrer, J.N. and Sherman, J., Eds., The Participatory Turn: Spirituality, Mysticism, Religious Studies, Suny Press, Albany, 135-169.

[17] Lattuanda, P.L. (n.d.) Second Attention Epistemology. Integral Transpersonal Institute. https://www.academia.edu/15602478/SecondAttention_Epistemology

[18] Dane, E. and Pratt, M.G. (2007) Exploring Intuition and Its Role in Managerial Decision Making. Academy of Management Review, 32, 33-54.

https://doi.org/10.5465/amr.2007.23463682 https://journals.aom.org/doi/10.5465/amr.2007.23463682

[19] Salas, E., Rosen, M.A. and Diez Granados, D. (2009) Expertise-Based Intuition and Decision Making in Organizations. Journal of Management, 36, 941-973.

https://doi.org/10.1177/0149206309350084

https://journals.sagepub.com/doi/abs/10.1177/0149206309350084 
[20] Plotkin (2003) Soulcraft: Crossing into the Mysteries of Nature and Psyche. New World Press, Novato.

[21] Louchakova, O. (2005) Ontopoieses and Union in the Prayer of the Heart: Contributions to Psychotherapy and Learning. In: Tymeinjecha, A.-T., Ed., Analecta Husserliana: Logos of Phenomenology and Phenomenology of the Logos, Book Four, Springer, Vol. 91, Dordrecht, 289-311. https://doi.org/10.1007/1-4020-3737-6_21

[22] Armour, J.A. (1991) Anatomy and Function of the Intrathoracic Neurons Regulating the Mammalian Heart. In: Zucker, I.H. and Gilmore, J.P., Eds., Reflex Control of the Circulation, CRC Press, Boca Raton, 1-37.

[23] Armour, J.A. (2007) The Little Brain on the Heart. Cleveland Clinic Journal of Medicine, 74, 48-51. https://doi.org/10.3949/ccjm.74.Suppl_1.S48

[24] Armour, J.A. (2008) Potential Clinical Relevance of the "Little Brain" on the Mammalian Heart. Experimental Physiology, 93, 165-176. https://doi.org/10.1113/expphysiol.2007.041178

[25] McCraty, R. (2009) The Coherent Heart-Brain Interactions, Psycho Physiological Coherence, and the Emergence of System-Wide Order. Integral Review, 5, 11-114.

[26] McCraty, R., Atkinson, M. and Bradley, R.T. (2004) Electrophysiological Evidence of Intuition. Part 1. The Surprising Role of the Heart. Journal of Alternative and Complementary Medicine, 10, 133-143. https://doi.org/10.1089/107555304322849057

[27] McCraty, R., Atkinson, M. and Bradley, R.T. (2004b) Electrophysiological Evidence of Intuition. Part 2. A System Wide Process? Journal of Alternative and Complementary Medicine, 10, 325-336. https://doi.org/10.1089/107555304323062310

[28] HeartMath Institute (2016) Heart-Brain Communication. https://www.heartmath.org/research/science-of-the-heart/heart-brain-communic ation

[29] Oschman, J.L. (2009) The Music of the Heart: A Personal Journey. Subtle Energies and Energy Medicine, 20, 9-35.

[30] Ramírez, J.M. (1991) Similarities in Attitudes towards Interpersonal Aggression in Finland, Poland and Spain. Journal of Social Psychology, 13, 737-739. https://doi.org/10.1080/00224545.1991.9924656

[31] Lindhard, T. (2015) Emotions Including Anger, Bodily Sensations and the "Living Matrix." The Open Psychology Journal, 8, 3-10. https://doi.org/10.2174/1874350101508010003 http://benthamopen.com/TOPSYJ/VOLUME/8/ISSUE/001

[32] Louchakova, O. (2007) Spiritual Heart and Direct Knowing in the Prayer of the Heart. Existential Analysis, 18, 81-102.

[33] Lindhard, T. (2018c) When a Virgin Is Not a Virgin. Advances in Social Sciences Research Journal, 5, 475-487.

[34] James, G.G.M. (1954) Stolen Legacy. Sacred Texts. http://www.sacred-texts.com/afr/stle/stle07.htm

[35] Roach, J. (2001) Delphic Oracle's Lips May Have Been Loosened by Gas Vapors. In National Geographic News. https://news.nationalgeographic.com/news/2001/08/0814_delphioracle.html

[36] Plutarch, M. (1936) The Obsolescence of Oracles. Loed Classical Library, Vol. V. https://doi.org/10.4159/DLCL.plutarch-moralia_obsolescence_oracles.1936 http://penelope.uchicago.edu/Thayer/E/Roman/Texts/Plutarch/Moralia/De_defectu _oraculorum ${ }^{\star} \cdot$ html 
[37] Fontenrose, J.E. (1974) The Delphic Oracle, Its Responses and Operations, with a Catalogue of Responses. University of California Press, Berkeley.

[38] Maurizio, L. (2001) The Voice at the Centre of the World: The Pythia's Ambiguity and Authority. In: Lardinois, A. and McClure, L., Eds., Making Silence Speak. Women's Voices in Greek Literature and Society, Princeton University Press, Princeton.

[39] Arka, S. (2006) Adventures of Self Discovery: The Journey from Mind to Heart to Consciousness. Antony Rowe, Surrey.

[40] Kates, J. (2014) The Glory That Was Greece. The Grandeur That Was Rome. Harvard Review.

http://harvardreview.fas.harvard.edu/?q=features/lorem-ipsum/glory-was-greece-gr andeur-was-rome

[41] Beard, M. (2013) Confronting the Classics: Traditions, Adventures and Innovations. Liveright Publishing Corporation, New York.

[42] Broad, W.J. (2007) $\Omega$. The Oracle Ancient Delhi and the Science about Its Secrets. Penguin Books, New York.

[43] Deulofeu, O., Klos, J., Mitchell, R., Orlikoski, T., Richards, R. and Spencer, L. (2008) Oracles of Delphi. In Rosicrucian Digest, No 2.

https://1df116ccf7e76f4fadc6db61b658f2565d5f24ddeaaa20b9f7d5.ssl.cf5.rackcdn.co m/w_06_Oracles.PDF

[44] Campbell, J. (2013) Excerpt from the Power of Myth. In Sunshine Recorder. https://sunrec.tumblr.com/post/49042928209/excerpt-from-the-power-of-myth-byjoseph

[45] Jung, C.G. (1938) Psychology and Religion. In: Jung, C.G., Ed., Psychology and Religion: West and East, Vol. 11, Princeton University Press, New York.

[46] Jung, C.G. (1951) Phenomenology of the Self. In: Campbell, J., Ed., The Portable Jung, Viking, New York, 147. https://en.wikipedia.org/wiki/Shadow_(psychology)\#cite_note-6

[47] Jung, C.G. (2002) Psychology of the Unconscious. Trans. Hinkle, B.M., Dover Publications, New York.

[48] Santayana, G. (1905) Reason in Common Sense. In: The Life of Reason, Vol. 1, Dover Publications, New York.

[49] Merriam-Webster.com (n.d.) Intuition. https://www.merriam-webster.com/dictionary/intuition

[50] Merriam-Webster.com (n.d.) Reason. https://www.merriam-webster.com/dictionary/reason

[51] Spencer, H. (2018) The Rational Intuitionist: An Appeal for a Modern Intuitive Approach to Replace Unbalanced Rationalism. https://herbspencer.academia.edu/research\#papers

[52] Utts, J. (2017) Appreciating Statistics. Journal of the American Statistical Association, 111, 1373-1380. https://doi.org/10.1080/01621459.2016.1250592 https://www.tandfonline.com/doi/full/10.1080/01621459.2016.1250592

[53] La Tour, S. and La Tour, K. (2011) Original Mind and Cosmic Consciousness in the Co-Creative Process. Frontiers of Philosophy in China, 6, 57-74. https://doi.org/10.1007/s11466-011-0125-7

[54] Paramthottu, J.V. (2011) Pre-Socratic Philosophers PPP Compilation. Author Stream. http://www.authorstream.com/Presentation/Paramthottu-1200841-pre-socratics-pp p-compilation 
[55] Scott, M. (2015) Delphi: A History of the Center of the Ancient World. Princeton University Press, Princeton and Oxford.

[56] Violatti, C. (2013) Greek Philosophy. Ancient History Encyclopedia. https://www.ancient.eu/Greek_Philosophy

[57] Daniels, V. (1997) Psychology in Greek Philosophy. Western Psychological Association Conference, Seattle, 26 April 1997. http://web.sonoma.edu/users/d/daniels/Greeks.html

[58] Sandford, E.M. (1938) The Mediterranean World. The Arnold Press Co., New York. https://archive.org/details/in.ernet.dli.2015.166853

[59] Vial, C.H. (1909) Ancient Mysteries. Macoy Publishing and Masonic Supply and Co., New York. https://archive.org/stream/Ancient_Mysteries_And_Modern_Masonry_-_C_H_Vai 1/Ancient_Mysteries_And_Modern_Masonry_-_C_H_Vail_djvu.txt

[60] Grof, S. and Grof, C. (2010) Holotropic Breathwork: A New Approach to Self-Exploration and Therapy. State University of New York Press, Albany.

[61] Velmans, M. (2009) How to Define Consciousness and How Not to Define Consciousness. Journal of Consciousness Studies, 16, 139-156.

[62] Ramabrahmam, V. (2007) The Physics and Electronics Meaning of Vivartanam. http://philpapers.org/rec/RAMTPA-2

[63] Raju, P.T. (2006) Idealistic Thought of India. Hesperides Press.

[64] Stenudd, (n.d.) Tao Te Ching-Chapter 6. Taoistic. http://www.taoistic.com/taoteching-laotzu/taoteching-06.htm

[65] Anderson, R. (2017) Lao-Tzu's Tao Te Ching: The Conscious Feminine Path to Peace from Ancient China. ITP Conference "Beyond Materialism-Towards Wholeness", Prague, 28 September-1 October 2017. http://www.itcprague2017.org/program

[66] Bohm, D. (1980) Wholeness and the Implicate Order. Routledge, London.

[67] Hagelin, J. (2014) Is Consciousness the Unified Field? Science and Nonduality. https://www.youtube.com/watch?v=LPhgDfT4Zpc

[68] Bhagavad Gita (n.d.). https://erenow.net/common/the-bhagavad-gita-classics-of-indian-spirituality/15.php

[69] Arkintime Be (2008) Ancient Egypt. http://www.arkintime.com/know-thyself/ancient-egypt

[70] Lufityato, G., Donkin, C. and Pearson, J. (2016) Measuring Intuition: Nonconscious Emotional Information Boosts Decision Accuracy and Confidence. Psychological Science, 1-13. https://doi.org/10.1177/0956797616629403

[71] Driver, J., Haggard, P. and Shallice, T. (2007) Introduction. Mental Properties in the Human Brain. Philosophical Transactions of the Royal Society B: Biological Sciences, 362, 757-760. https://doi.org/10.1098/rstb.2007.2085

[72] Koch, C. (2018) What Is Consciousness. Scientists Are Beginning to Unravel a Mystery That Has Long Vexed Philosophers. Nature, 557, S8-S12.

https://doi.org/10.1038/d41586-018-05097-x https://www.nature.com/articles/d41586-018-05097-x

[73] Irikil, A. and Sakura, S. (2008) The Neuroscience of Primate Intellectual Evolution: Natural Selection and Passive and Intentional Niche Construction. Philosophical Transactions of the Royal Society B, 363, 2229-2241. https://doi.org/10.1098/rstb.2008.2274

[74] Nishijo, H., Rafal, R. and Tamietto, M. (2018) Editorial: Limbic-Brainstem Roles in 
Perception, Cognition, Emotion, and Behavior. Frontiers in Neuroscience, 12, Article 306. https://doi.org/10.3389/fnins.2018.00395

[75] Arka, S. (2009) Arka Dhyana. An Adventure of Self-Discovery through the Practice of Intuitive Meditation. Coppersun Books, Middlesex.

[76] Louchakova, O. (2003) Prayer of the Heart as an Essential Activity of the Self: A Cross-Disciplinary Enquiry into the Cultural-Historical Modes of Spiritual Practice. https://www.academia.edu/22830969/Prayer_of_the_Heart_as_an_Essential_Activit y_of_the_Self_A_Cross-Disciplinary_Enquiry_into_the_Cultural-Historical_Modes _of_Spiritual_Practice

[77] Louchakova, O. (2008) Reconstruction of the Self during the Study of Advaita Vedanta (Traditional Indian Teaching of Non-Dual Consciousness: Phenomenological Investigations.) toward a Science of Consciousness, 8-12, Tuscon, AZ. Consciousness Research Abstracts, 315, 194.

[78] Louchakova-Schwartz, O. (2014) The Symphony of Sentience, in Cosmos and Life: In Memoriam A.-T.T. Agathos.

https://www.academia.edu/8955257/LouchakovaSchwartz_Olga.2015._The_Symphon Y_of_Sentience_in_Cosmos_and_Life_In_Memoriam_A.T.T.T.Agathos_to_appear

[79] Lindhard, T. (2019) Consciousness from the Outside-In and Inside-Out Perspective. Journal of Consciousness Exploration \& Research, 10, 136-150.

[80] Qualls-Corbett, N. (1988) The Sacred Prostitute: Eternal Aspect of the Feminine. Inner City Books, Toronto.

[81] Samples, B. (1976) The Metaphoric Mind: A Celebration of Creative Consciousness. Addison-Wesley Publishing Company, Reading. 